http://dx.doi.org/10.11646/phytotaxa.164.1.4

\title{
Bartsia lydiae, a new species of Bartsia sect. Laxae (Orobanchaceae) from the southern Peruvian Andes with a revised key to Bartsia sect. Laxae
}

\author{
STEVEN P. SYLVESTER ${ }^{1}$ \\ ${ }^{I}$ Institute of Systematic Botany, University of Zurich, Zurich, Switzerland. \\ E-mail: stevenpaul.sylvester@uzh.ch
}

\begin{abstract}
A new species of Bartsia sect. Laxae is described and illustrated from the Cordillera Vilcanota, southern Peru. The species is distinct from all other members of sect. Laxae in being covered with persistent glandular hairs and having a reddish purple corolla. The species is a common element of undisturbed puna vegetation in the Cordillera Vilcanota, being associated with Polylepis forests. A revised key to Bartsia sect. Laxae is included to accommodate this new species.
\end{abstract}

\section{Introduction}

The genus Bartsia Linnaeus (1753: 602) comprises 49 species, its centre of diversification being in the Andes of South America with 45 species endemic to this area (Molau 1990). Peru contains the largest diversity of Bartsia with 35 species (Brako \& Zarucchi 1993, Ulloa et al. 2004) found scattered throughout the Andean foothills and mountain chain, 14 of which are endemic (León 2006). Bartsia sect. Laxae Molau (1990: 50) is a morphologically well-defined group currently containing 10 species which are distributed from Venezuela to Bolivia and Chile. The section is distinguished by a campanulate calyx with the lobes reflexed from mid anthesis and an exserted capitate stigma. The taxonomy of Bartsia is still in debate with recent phylogenetic studies (Scheunert et al. 2012) suggesting the transfer of all South American Bartsia species to the resurrected genus Bellardia All. (1785: 61). Scheunert et al. (2012) do clearly state, however, that this is perhaps premature as only 3 out of the, now, 46 Andean Bartsia's have been sequenced to date including just one species from sect. Laxae.

Bartsia, in the past, was considered notoriously difficult due to the superficial similarities of herbarium specimens and the occurrence of many mixed herbarium collections which deterred most taxonomists from attempting to revise the genus. Despite these difficulties, Molau (1990) produced the first concise world revision of the genus, benefitting the taxonomy of Bartsia immensely and allowing the specimens collected to be easily recognised as a species new to science. Based on morphological studies of dry and living material in collections and field studies, I describe this new species of Bartsia sect. Laxae with a persistent glandular-pubescent indumentum and reddish purple corolla, morphologically distinct from all other species of sect. Laxae.

\section{Taxonomy}

Bartsia lydiae S.P.Sylvester, sp. nov. (Fig. 1-3)

Species perenne distincta ab aliis speciebus notis sect. Laxae, a quibus caulibus vel foliabus hirsutus, pilis glandulosis, corolla purpurea.

Type:-PERU. Cusco, Prov. Urubamba: Distr. Urubamba, Área de Conservación Privada (ACP) Mantanay, $10 \mathrm{~km}$ up the valley from Yanahuara in the small valley $3 \mathrm{~km}$ E of laguna Ipsaycocha, forest on the SW side of laguna Manalloqsa, 4614m, S13 11' 59.2" W72 08' 39.9", 23 June 2012, S.P. Sylvester 1754 (holotype USM!, isotypes CUZ!, GB!, ID!, MO!, Z!) 
8. Inflorescence dense, subspicate, the upper bracts prominent, lanceolate to subulate, acute or acuminate, entire or laciniatedentate, strigose with mostly eglandular hairs B. bartsioides

- Inflorescence loose, the bracts smaller than foliage leaves, crenate, dentate or entire, at least the upper ones glandularhirsute

9. Corolla with the galea orange-red and the lip bright yellow, the galea $1.4-1.7 \times$ the length of the lip ............ B. camporum

- $\quad$ Corolla purple to deep red throughout, lip sometimes yellow-green, but then the galea $1.8-2.4 \times$ the length of the lip .... 10

10. Calyx 10-15 mm long, the lobes straight, never reflexed; corolla lip yellow-green ............................... B. weberbaueri

- Calyx 6-15 mm long, when more than $10 \mathrm{~mm}$ long the corolla lip usually red; calyx lobes reflexed............... B. inaequalis

\section{Acknowledgements}

This research was funded by a studentship grant from The Leverhulme Trust, UK. Thanks go to Prof. Dr. Ulf Molau, who confirmed B. lydiae to be a new species to science and allowed the revision of his original key to sect. Laxae. Dr. Michael Kessler and two anonymous reviewers are thanked for advice in the preparation of the manuscript. METI and NASA are thanked for providing the ASTER digital elevation map.

\section{References}

Allioni, C. (1785) Flora Pedemontana sive Enumeratio Methodica Stirpium Indigenarum Pedemontii. Vol. 1. Joannes Michael Briolus, Turin, $366 \mathrm{pp}$.

Brako, L. \& Zarucchi, J. (1993) Catalogue of the Flowering Plants and Gymnosperms in Peru. Monographs in Systematic Botany from the Missouri Botanical Garden 45: 1-1286.

León, B. (2006) Endemic Orobanchaceae of Peru. Revista Peruana de Biología 13 (2): 478-481.

Linnaeus, C. (1753) Species Plantarum 2. Imprensis Laurentii Salvii, Holmiae, Sweden, pp. 561-1200. http://dx.doi.org/10.5962/bhl.title.669

Molau, U. (1990) The genus Bartsia (Scrophulariaceae: Rhinanthoideae). Opera Botanica 102: 1-99.

Ruiz, H. \& Pavon, J.A. (1794) Florae Peruvianae, et Chilensis Prodromus. Imprenta de Sancha, Madrid, pp. 153. http://dx.doi.org/10.5962/bhl.title.11759

Scheunert, A., Fleischmann, A., Olano-Marín, C., Bräuchler, C. \& Heubl, G. (2012) Phylogeny of tribe Rhinantheae (Orobanchaceae) with a focus on biogeography, cytology and re-examination of generic concepts. Taxon 61: $1269-1285$.

Ulloa Ulloa, C., Zarucchi, J. \& León, B. (2004) Diez años de adiciones a la flora del Perú: 1993-2003. Arnaldoa, Ed. Especial 7-242. http://dx.doi.org/10.5962/bhl.title.63538

Zerbe, S. (1998) Potential natural vegetation- validity and applicability in landscape planning and nature conservation. Journal of Applied Vegetation Science 1: 165-172. 